\title{
Assessing the current state of commercially available membranes and spacers for energy production with pressure retarded osmosis
}

* Corresponding author: e-mail: tcath@ mines.edu; phone: (303) 273-3402; fax: (303) 273-3413

${ }^{1}$ Colorado School of Mines, Golden, CO, USA

${ }^{2}$ Yale University, New Haven, CT, USA

\section{A manuscript prepared for possible publication in Desalination}

September 2015 


\begin{abstract}
Pressure Retarded Osmosis (PRO) is an osmotically driven membrane process that utilizes the energy of mixing between streams of high and low chemical potential to generate electrical energy. High power density of a PRO membrane is essential to maximize process efficiency and minimize the capital and operating costs. Thus, robust PRO membranes that can support high pressure, have high water flux, low reverse salt flux, low structural parameter, and a good membrane support structure are needed. In this study, four commercial forward osmosis (FO) membranes for use in PRO were compared. The effect of operating pressures, membrane spacers (type, orientation, and arrangement), and flow velocities on process performance were investigated. A thin film composite polyamide membrane from Hydration Technology Innovations was found to be the most robust and selective membrane. Compared to other spacer configurations, the use of unique feed channel spacer orientations was found to increase PRO power density by up to $46 \%$, yielding power density of $22.6 \mathrm{~W} / \mathrm{m} 2(3 \mathrm{M} \mathrm{NaCl}$ draw solution and 4.1 MPa hydraulic pressure). However, membrane deformation was observed when operating pressures exceeded 3.5 $\mathrm{MPa}$. The use of unique spacers coupled with decreased draw solution cross-flow velocities was found to increase PRO process efficiency.
\end{abstract}

Keywords: Osmotic power; pressure retarded osmosis; power density; energy-water nexus; membrane integrity 


\section{Introduction}

Water and energy are interdependent and are increasingly in demand in both developed and developing countries, mainly due to population growth and economic expansion. Accordingly, it is essential to develop advanced technologies that maximize energy production, minimize emissions, reduce water consumption, and lessen reliance on fossil energy resources. In 2013, energy consumption surmounted energy production in the U.S. (where the remaining energy resources were imported), and only $11 \%$ of the energy produced in the U.S. was from renewables [1]. Renewable energy resources from water, or blue energy, are abundant and dependable [2, 3]; they include hydropower, geothermal, wave, tidal, algae biofuel, and salinity gradient energy.

Osmotic power, or salinity gradient power, harnesses the energy of mixing between high and low salinity streams. Pressure retarded osmosis (PRO) is an osmotically driven membrane process that can facilitate conversion of the energy of mixing to mechanical energy, which can further be converted to electrical energy [4-6]. In PRO, water permeates by osmosis through a semi-permeable membrane from a low concentration feed stream into a higher concentration brine (a.k.a. draw solution). The draw solution becomes diluted but is not allowed to spontaneously expand; thus, it is pressurized to a hydraulic pressure less than the osmotic

pressure difference between the draw solution and feed. As a result, the net driving force for transport of water (permeate stream) remains in the direction of feed to the draw solution. The energy in the pressurized, diluted draw solution can then be converted into electrical energy via a turbine-generator set. Proposed configurations of PRO include stand alone PRO for energy recovery from mixing of low concentration (e.g., river water) and high concentration waters (e.g., Dead Sea, Great Salt Lake, or seawater) [4-11], PRO coupled with RO for low-energy desalination [12-14], and PRO hybridized with a thermal distillation process for energy generation from low-grade heat [15-18].

The cost, selectivity, and robustness of PRO membranes have been identified as the main limitations for commercialization of osmotic power [10, 19]. Currently, commercial PRO membranes are not available; therefore, forward osmosis (FO) membranes are used in all PRO investigations [20]. Ideally, PRO membranes would demonstrate high water permeability and high selectivity. Membranes with high selectivity limit the transport and accumulation of draw 
solution solutes in the feed solution, which would otherwise result in a lower driving force and lower energy recovery [21-23].

Power density is an important performance parameter in PRO and it is defined as the amount of power generated (in watts) per unit membrane area used. In general, the maximum power density is determined by multiplying the water flux through the PRO membrane by the hydraulic pressure in the draw solution. Mathematically, the maximum power density for specific operating conditions occurs at an applied pressure equal to half of the osmotic pressure of the draw solution [19]. In order to achieve high PRO power density, internal and external concentration polarization (CP) $[8,19,21,22,24-27]$ - two phenomena governing process performance in osmotically driven membrane processes - must be minimized. When water permeates from the low concentration feed to the high concentration draw solution, the draw solution at the draw solution-membrane interface becomes diluted and the osmotic pressure driving force across the membrane declines. This phenomenon is defined as external CP (ECP). Internal $\mathrm{CP}$ (ICP) in PRO is defined as the accumulation of salt in the membrane support structure, which also reduces the osmotic pressure driving force in PRO. Increased mixing and mass transfer at the feed and draw solution-membrane interfaces can reduce ECP. High crossflow velocities and turbulence-enhancing spacers can be used to increase mixing; however, increasing flow velocities comes at the expense of increased pumping and pressure losses, which result in decreased net energy production.

High power density in PRO can also be generated by operating with high concentration draw solutions (i.e., high osmotic pressure) and thus high hydraulic pressures in the draw solution channels; therefore, PRO membranes must be mechanically stable at high operating pressures. Results from recent studies have shown increased mechanical stability of PRO membranes when feed-side tricot spacers (i.e., a densely woven mesh spacer typically used as a permeate carrier in reverse osmosis (RO) spiral wound membrane elements) are used [28, 29]. In addition to providing better support for the membrane against the high pressure in the draw solution channels, membrane spacers must provide good mixing and adequate flow passage, thus reducing energy loss induced by flow resistance in the PRO feed and draw solution flow channels (Fig. 1) [29-35]. Poor selection of feed channel spacers can lead to increased feed channel pressure drops in PRO membrane modules and cause a membrane shadow effect (reduced effective membrane area and power density); both of which ultimately decrease net 
power output. Therefore, additional research is needed to optimize PRO membrane performance and spacer selection.

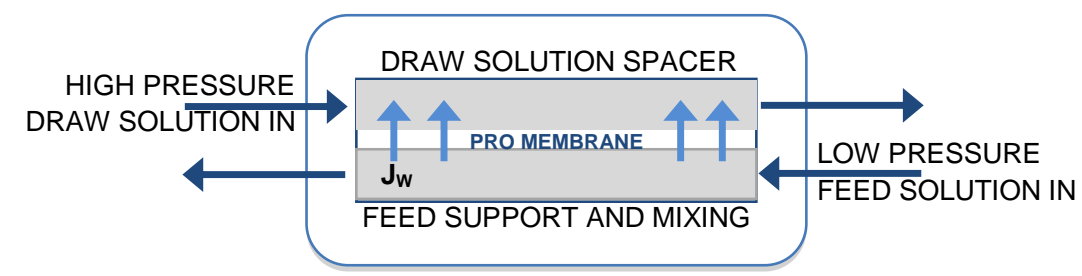

Fig. 1. Schematic of the PRO membrane flow cell with feed and draw solution spacers.

The main objectives of this study were to assess the performance of commercially available FO membranes for application in PRO and to evaluate key operating parameters for increased power density. Several commercial FO membranes were tested in PRO mode, and were evaluated in terms of water flux, reverse solute flux, power density, and mechanical integrity (i.e., burst pressure). Experiments were performed over prolonged periods of time to evaluate the effects of high operating pressures (up to $4.8 \mathrm{MPa}$ (700 psi)) on membrane performance and mechanical stability. Finally, the use of unique spacer configurations and varying cross-flow velocities were evaluated in terms of their influence on PRO mass transfer, membrane cell pressure drop, and power densities.

\section{Material and methods}

Four commercial FO membranes were tested in a bench-scale system for use in PRO. Different feed and draw solution spacer configurations and orientations and different flow rates were used to evaluate their effect on mass transfer and process performance, including salt flux and process efficiency.

\subsection{Membranes}

Commercial, semipermeable, flat-sheet FO membranes were acquired from Hydration Technology Innovation (HTI) (Albany, OR), Oasys Water (Boston, MA), and from a third company, referred to as company $\mathrm{X}$ in this article. Membranes from HTI, Oasys, and $\mathrm{X}$ are polyamide-based, thin-film composites (TFC), and one additional membrane from HTI is made of cellulose triacetate (CTA). 


\subsection{Determination of membrane properties}

Membrane properties (Table 1) were experimentally determined using methodologies previously proposed as standard methods [36]. The HTI TFC and CTA membranes were precompacted with a $50 \mathrm{mM} \mathrm{NaCl}$ draw solution at $3.1 \mathrm{MPa}(450 \mathrm{psi})$ until the flux stabilized. The Oasys and X TFC membranes were not pre-compacted because of their low operating pressures (1.0 MPa (150 psi)). The membrane water permeability (A) and salt permeability (B) were determined by performing experiments in a modified RO mode [19, 35] using the PRO flow cell. The permeate stream (circulated in the PRO feed channel) was deionized water and the feed solution (circulated in the PRO draw solution channel) was $50 \mathrm{mM} \mathrm{NaCl}$. The feed solution was pressurized at increasing pressure intervals of $690 \mathrm{kPa}(100 \mathrm{psi})$ for high-pressure membranes (HTI TFC and CTA) and $340 \mathrm{kPa}$ (50 psi) for low-pressure membranes (Oasys and X TFC). The mass transfer coefficient (k) was determined from the cell geometry, solution chemistries, spacer geometry, and operating flows [34]. Membrane burst pressure was found by closely monitoring the feed solution conductivity over each pressure interval, and the membrane was determined compromised when the feed solution conductivity sharply increased by more than $1,500 \mu \mathrm{S}$ over a 10-minute period.

Table 1. Membrane water permeability (a), salt permeability (B), water/solute selectivity, structural parameter $(\mathrm{S})$, and burst pressure for X, Oasys, and HTI membranes. The HTI TFC and CTA membranes were pre-compacted at 3.1 $\mathrm{MPa}$.

\begin{tabular}{llllll}
\hline Membrane & $\begin{array}{l}\mathrm{A}, \\
10^{-2} \mathrm{~L} / \mathrm{m}^{2}-\mathrm{hr}-\mathrm{kPa}\end{array}$ & $\begin{array}{l}\mathrm{B}, \\
\mathrm{L} / \mathrm{m}^{2}-\mathrm{hr}\end{array}$ & $\begin{array}{l}\mathrm{A} / \mathrm{B}, \\
10^{-2} / \mathrm{kPa}\end{array}$ & $\begin{array}{l}\mathrm{S}, \\
\mu \mathrm{m}\end{array}$ & $\begin{array}{l}\text { Burst } \\
\text { pressure, } \\
\mathrm{MPa}(\mathrm{psi})\end{array}$ \\
\hline $\mathrm{X}$ & 1.50 & 3.76 & 0.40 & 159 & $1.0(150)$ \\
Oasys & 1.94 & 1.99 & 0.97 & 274 & $1.0(150)$ \\
HTI CTA & 0.51 & 2.19 & 0.23 & 600 & $3.5(500)$ \\
HTI TFC & 1.63 & 1.42 & 1.15 & 295 & $4.8(700)$ \\
\hline
\end{tabular}

\subsection{Membrane cells}

A stainless steel modified SEPA-CF II cell (GE Water \& Process Technologies) was used in this study. The active surface area of the membrane in the cell is $139 \mathrm{~cm}^{2}$, with a feed and draw solution flow channel depth of $1 \mathrm{~mm}$. Viton O-rings were placed on the outer edge of the draw solution channel and outer perimeter of the cell to prevent leakage and cross contamination of 
the feed and draw solution streams. The feed and draw solution spacers were taped to the cell to prevent tearing of the membranes at the rims of the channels. Taping of the spacers decreased the effective membrane surface area to $124 \mathrm{~cm}^{2}$.

\subsection{Feed and draw solution spacers}

Tricot warp knit (Hornwood Inc., Lilesville, NC) and non-woven extruded mesh spacers were used in this investigation (Fig. 2). The spacer properties are summarized in Table 2. The number of carrier channels per inch and thickness characterize tricot warp knit spacers. The extruded mesh spacers have square openings with a filament length of $3.24 \mathrm{~mm}$. The spacer voidage was determined by a volumetric displacement method. A known amount of spacer area was submerged in deionized water. The voidage was determined by calculating the ratio of the volume of the free space in a spacer (through water displacement experiments) and the total spacer volume (known spacer area multiplied by total spacer thickness).

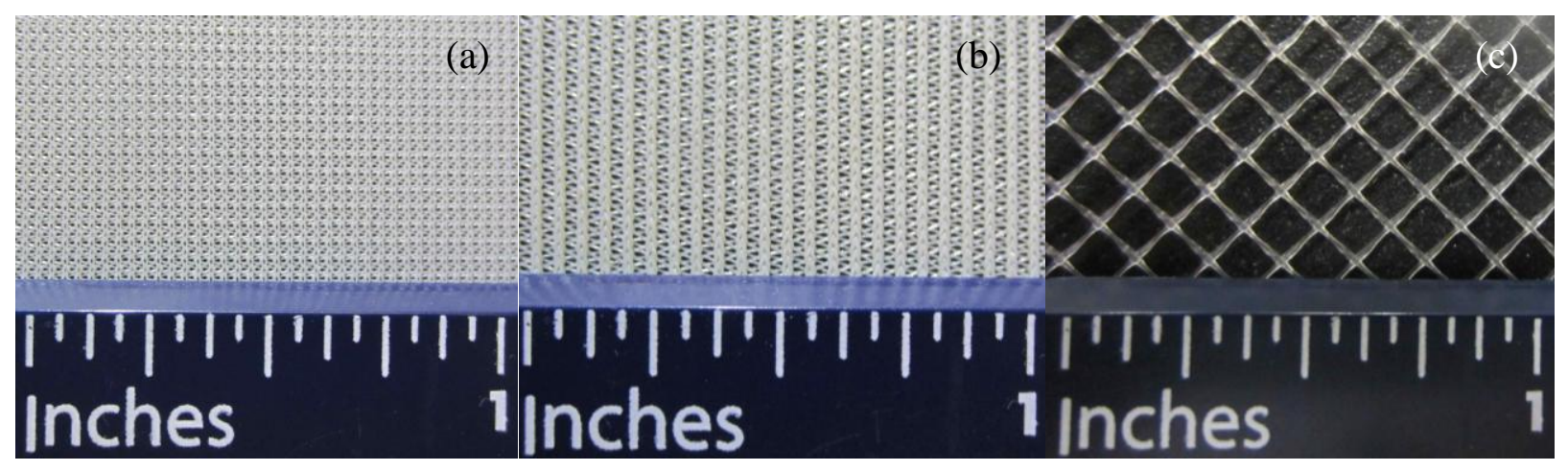

Fig. 2. Picture of the (a) 35-channel tricot, (b) 20-channel tricot, and (c) extruded mesh spacer.

Table 2. Spacer type, thickness, and voidage used in the experiments. The voidage was measured through a displacement method.

\begin{tabular}{llll}
\hline Spacer name & $\begin{array}{l}\text { Mesh } \\
\text { Type }\end{array}$ & $\begin{array}{l}\text { Thickness } \\
\mathrm{mm}\end{array}$ & $\begin{array}{l}\text { Voidage } \\
\%\end{array}$ \\
\hline 20-channel tricot & Warp knit & 0.5 & 64 \\
35-channel tricot & Warp knit & 0.25 & 36 \\
Diamond mesh & Extruded & 0.68 & 86 \\
\hline
\end{tabular}

Two layers of spacers were used in both the feed and draw solution channels, except if otherwise stated (Fig. 3). The draw solution spacer configurations investigated include two 
extruded mesh spacers, and an extruded mesh spacer with a 20-channel tricot spacer (nearest to membrane surface and parallel to the flow).

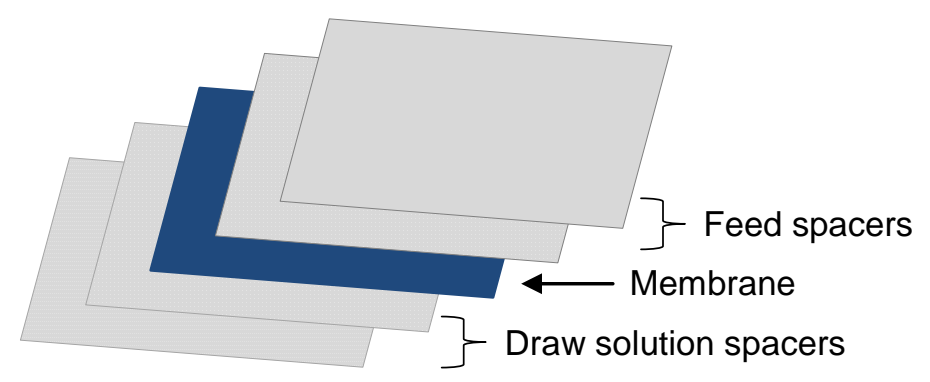

Fig. 3. Schematic of the spacer configuration in the PRO membrane flow cell.

Two types of tricot spacers (20-channel and denser 35-channel) were used for feed channel spacers. Feed spacer orientations for the 20-channel tricot spacers are shown in Fig. 4. The 35channel tricot spacers were oriented with the channels parallel to the feed flow (similar to Fig. $4 a)$; four of these spacers were used to fill the feed channel. All tricot spacers were oriented with carrier channels facing away from the membrane.
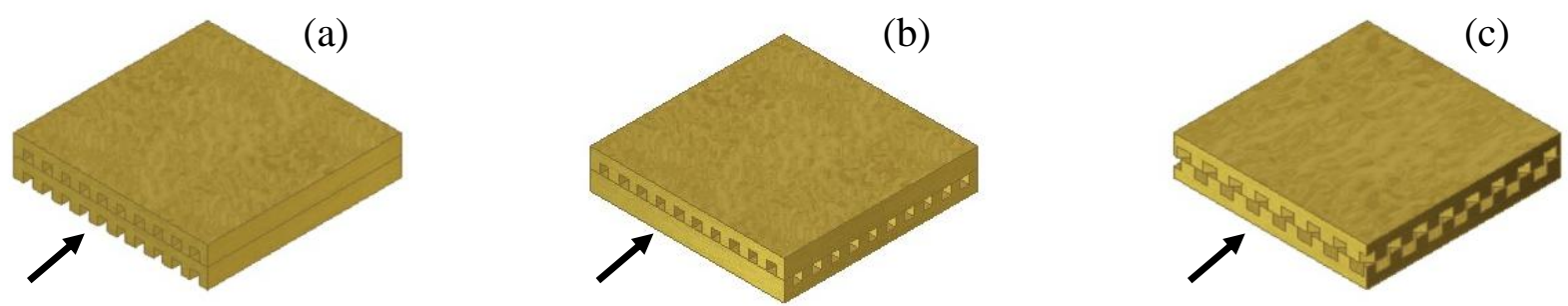

Fig. 4. Illustration of different feed spacer orientations for the 20-channel tricot spacers: (a) both channels oriented parallel to the flow, (b) one channel parallel and one channel at $90^{\circ}$ to the flow, and (c) both channels positioned at $45^{\circ}$ to the flow. The arrows indicate the direction of feed flow. The top spacer is in contact with the membrane and the bottom spacer is in contact with the flow cell.

\subsection{Bench scale system}

Bench scale experiments were performed to investigate water flux, reverse solute flux, power density, flow channel pressure drop, and PRO process efficiency. A supervisory control and data acquisition (SCADA) system (LabVIEW, National Instruments, Austin, TX; and LabJack, 
Lakewood, CO) was used to control and record pressures, flow rates, temperatures, and feed and draw solution concentrations.

A flow schematic of the test unit is illustrated in Fig. 5. The thermally insulated feed and draw solution reservoirs were connected to a gear pump (Micropump, Vancouver, WA) and a direct drive plunger pump (Cat Pumps, Minneapolis, MN), respectively, which circulated the two streams co-currently on the opposite sides of the membrane. In practice, the feed and draw solution would be circulated counter-currently; however, due to the small size of the test cell, operating in co-current mode has negligible effects on process performance. Echopod ultrasonic level sensors (FlowLine, Los Alamitos, CA) were installed on top of the draw solution, feed, and dosing solution reservoirs to monitor the levels of fluids, and thus calculate changes in volume in each reservoir. Pressure transducers (Omega Engineering, Stamford, CT) located at the inlets and outlets of the membrane cell monitored pressure drop in the feed and draw solution channels, and a proportional valve (Hass Manufacturing Co., Averill Park, NY) was used to control the hydraulic pressure in the draw solution flow channel in the membrane cell. Toroidal conductivity sensors (Sensorex, Garden Grove, CA), located at the membrane cell outlets, were used to monitor and facilitate the control of the feed and draw solution concentrations. A peristaltic pump (McMaster-Carr, Chicago, IL) was used to dose the draw solution with concentrated brine and maintain a constant draw solution concentration during the experiments. Stream temperatures were monitored with silicon crystal based sensors (LabJack, Lakewood, CO) and controlled with shell-and-tube heat exchangers, which were installed at the outlets of the membrane cell. 


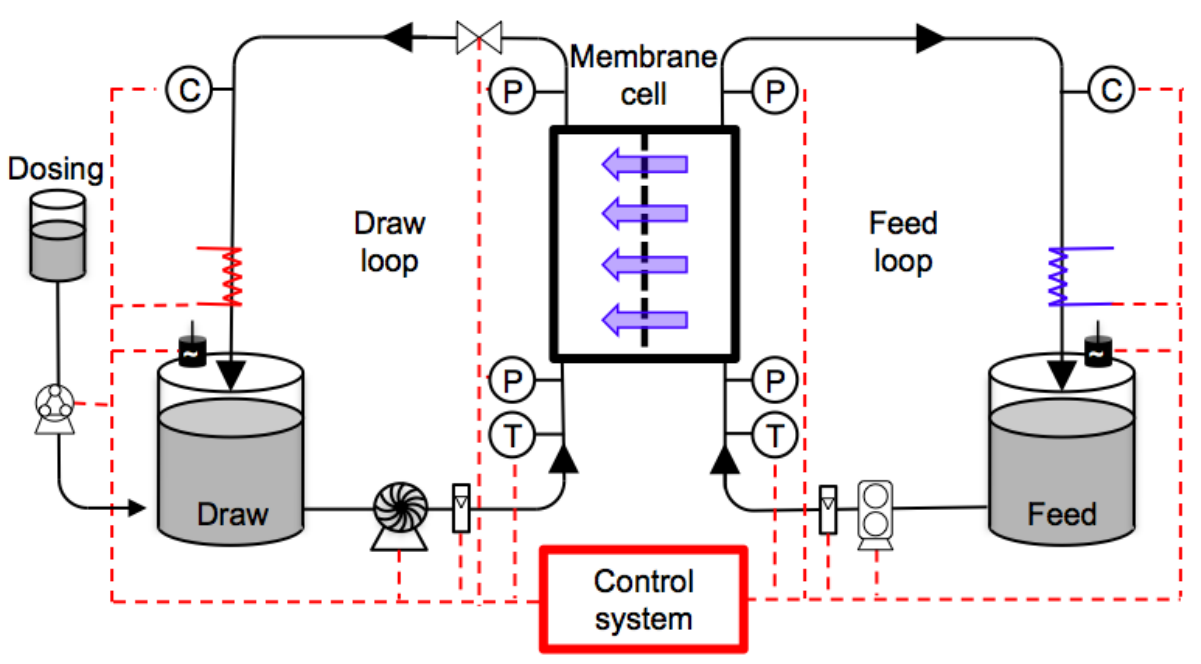

Legend

むUltrasonic sensor

(C) Conductivity probe

(P) Pressure transducer

(T) Temperature probe

₹ Heat exchanger

月 Flow meter

$\bigotimes$ Back pressure valve

8. Gear Pump

82 Peristaltic pump

Plunger pump

Fig. 5. Flow diagram of the bench scale PRO system used in the current study.

The feed and draw solution flow rates and temperatures were kept constant at $0.5 \mathrm{~L} / \mathrm{min}$ and $20{ }^{\circ} \mathrm{C}$, respectively, and the draw solution hydraulic pressure was varied between $340 \mathrm{kPa}$ (50 psi) and 4.8 $\mathrm{MPa}$ (700 psi). Changes in feed tank volume, feed solution conductivity, and membrane cell inlet and outlet pressures were used to calculate water flux, reverse solute flux, and feed channel pressure drop, respectively. Power density was calculated by multiplying the water flux by draw solution inlet pressure. The potential power generated in the PRO experiments was calculated by multiplying the power density by the membrane area. Specific reverse solute flux was determined through calculating the ratio between the reverse solute flux and water flux. PRO process efficiency was determined by calculating the ratio between the PRO power generated (power density $\times$ membrane area) and the sum of feed and draw solution pumping power $\left(\mathrm{W}_{\text {pump,feed }}+\mathrm{W}_{\text {pump,draw }}\right)$. The pumping power for the feed solution was calculated by multiplying the feed solution flow rate and feed inlet pressure, then dividing by the pump efficiency $\left(\mathrm{W}_{\text {pump }}=\mathrm{Q} \times \mathrm{P} \div \eta_{\text {pump }}\right)$. The pumping power for the draw solution was calculated by multiplying the draw solution flow rate, draw solution inlet pressure, and pressure exchanger (PX) efficiency, and dividing by the pump efficiency $\left(\mathrm{W}_{\text {pump }}=\mathrm{Q} \times \mathrm{P} \times\left(1-\eta_{\mathrm{PX}}\right) \div \eta_{\text {pump }}\right)$. A pump efficiency of $70 \%$ and a pressure exchanger efficiency of $95 \%$ were assumed.

\subsection{Solution chemistry}




\subsection{Water flux, power density, reverse solute flux, and mechanical stability of commercially available FO membranes for PRO}

Power density and specific reverse solute flux as a function of hydraulic pressure for the four membranes are shown in Fig. 6. The X, Oasys, and HTI TFC membranes all have similar power densities when tested at pressures lower than 1.0 MPa (150 psi) (Fig. 6a). However, the X and Oasys TFC membranes are limited to operation at pressures of up to $1.0 \mathrm{MPa}$ ( $150 \mathrm{psi})$; reverse solute flux sharply increases and the membrane's mechanical integrity becomes compromised at higher pressures. The HTI CTA and TFC membranes can withstand operation at pressures up to 3.5 $\mathrm{MPa}(\sim 500 \mathrm{psi})$ and 4.8 $\mathrm{MPa}(\sim 700 \mathrm{psi})$, respectively (Table 1$)$. Operating the HTI TFC membrane at an applied hydraulic pressure of $2 \mathrm{MPa}$ results in a membrane power density of 9 $\mathrm{W} / \mathrm{m}^{2}$. The HTI CTA membrane was one of the least permeable membranes. Compared to the TFC membranes, the CTA membrane is thicker and has a denser skin layer [20] and a higher structural parameter (Table 1), which results in lower water fluxes and power densities.

The HTI TFC membrane had the lowest specific reverse solute flux (highest selectivity), followed by the HTI CTA, X, and Oasys membrane (Fig. 6b). Although the HTI CTA membrane has a higher solute permeability compared to the Oasys membrane (Table 1), the membrane's mechanical integrity remains intact at higher operating pressures (up to $3.5 \mathrm{MPa}$ ). For all 
membranes, the specific reverse solute flux increased and the selectivity decreased with increasing applied pressures. Decreased membrane selectivity results in increased feed solution concentrations and thus a decreased net driving force. Over time, the solute concentration in the feed stream will continue to increase and power density will decrease-specific reverse solute fluxes higher than $5 \mathrm{~g} / \mathrm{L}$ reduce the effective driving force in PRO [19]. Additionally, solute accumulation in the feed stream is especially problematic in closed-loop PRO systems, such as in osmotic heat engines [15-18].

Although $\mathrm{X}$ and Oasys TFC membranes are limited to operating at low-pressure PRO applications (i.e., mixing of river water and seawater), it is important to note that these membranes are well suited for FO applications [37, 38]. Of the membranes investigates, the HTI TFC membrane demonstrated the highest mechanical strength, power density, and selectivity, and was used for the rest of the experiments.
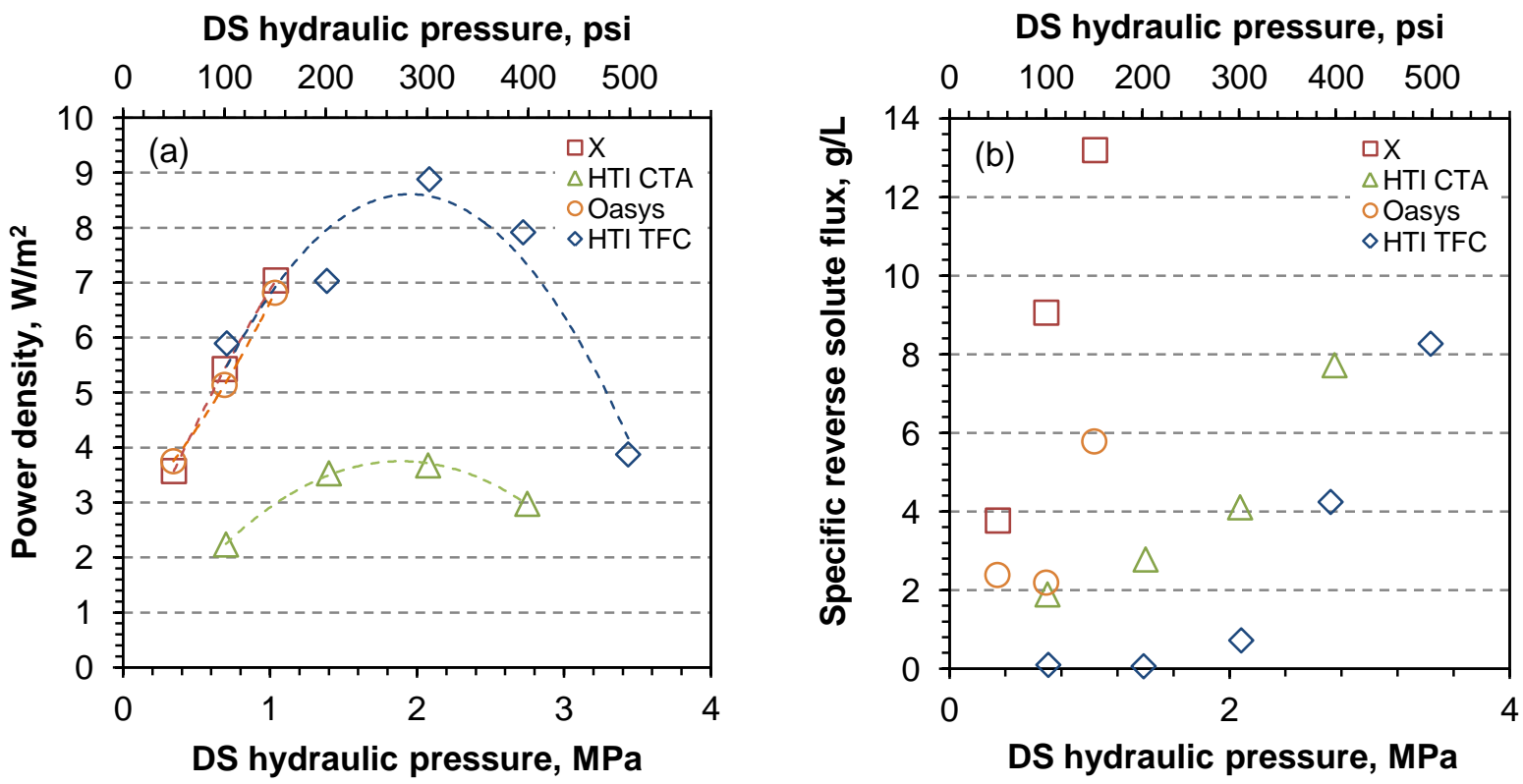

Fig. 6. (a) Power density and (b) specific reverse solute flux as a function of draw solution hydraulic pressure for the X, Oasys, and HTI TFC membranes and HTI CTA membrane. Experiments were conducted with stream temperatures of $20^{\circ} \mathrm{C}$, flow rates of $0.5 \mathrm{~L} \mathrm{~min}^{-1}$, deionized water as the feed, and a $1 \mathrm{M} \mathrm{NaCl}$ draw solution. Two parallel 20-channel spacers were used in in the feed channel and one 20-channel spacer with an extruded mesh spacer was used in the draw solution channel.

The performance of the HTI TFC membrane was evaluated with 1, 2, and $3 \mathrm{M} \mathrm{NaCl}$ draw solution concentrations (deionized water as the feed solution) with two parallel 20-channel tricot 
spacers in the feed channel and one 20-channel spacer and an extruded mesh spacer in the draw solution channel. Power density and specific reverse solute flux as a function of hydraulic pressure are shown in Fig. 7. Experiments were performed with multiple membrane coupons to eliminate bias due to manufacturing defects. The error bars represent the standard error amongst membrane coupons. Power density increased with increasing driving force (draw solution concentration) and draw solution hydraulic pressure. The specific reverse solute flux also increased with increasing draw solution hydraulic pressure. However, the increased driving force (concentration difference) does not affect specific reverse solute flux in PRO. Similar to FO, the reverse solute selectivity is independent of the draw solution concentration and is solely determined by the active layer selectivity and inherent number of dissolved species in the draw solute [22]. The standard error between membrane coupons for power density and specific reverse solute flux increased with increasing draw solution hydraulic pressure, indicating that the membrane was losing its mechanical integrity and more prone to deformation at applied hydraulic pressures higher than $3.5 \mathrm{MPa}$ (TMP of 3.3 MPa).
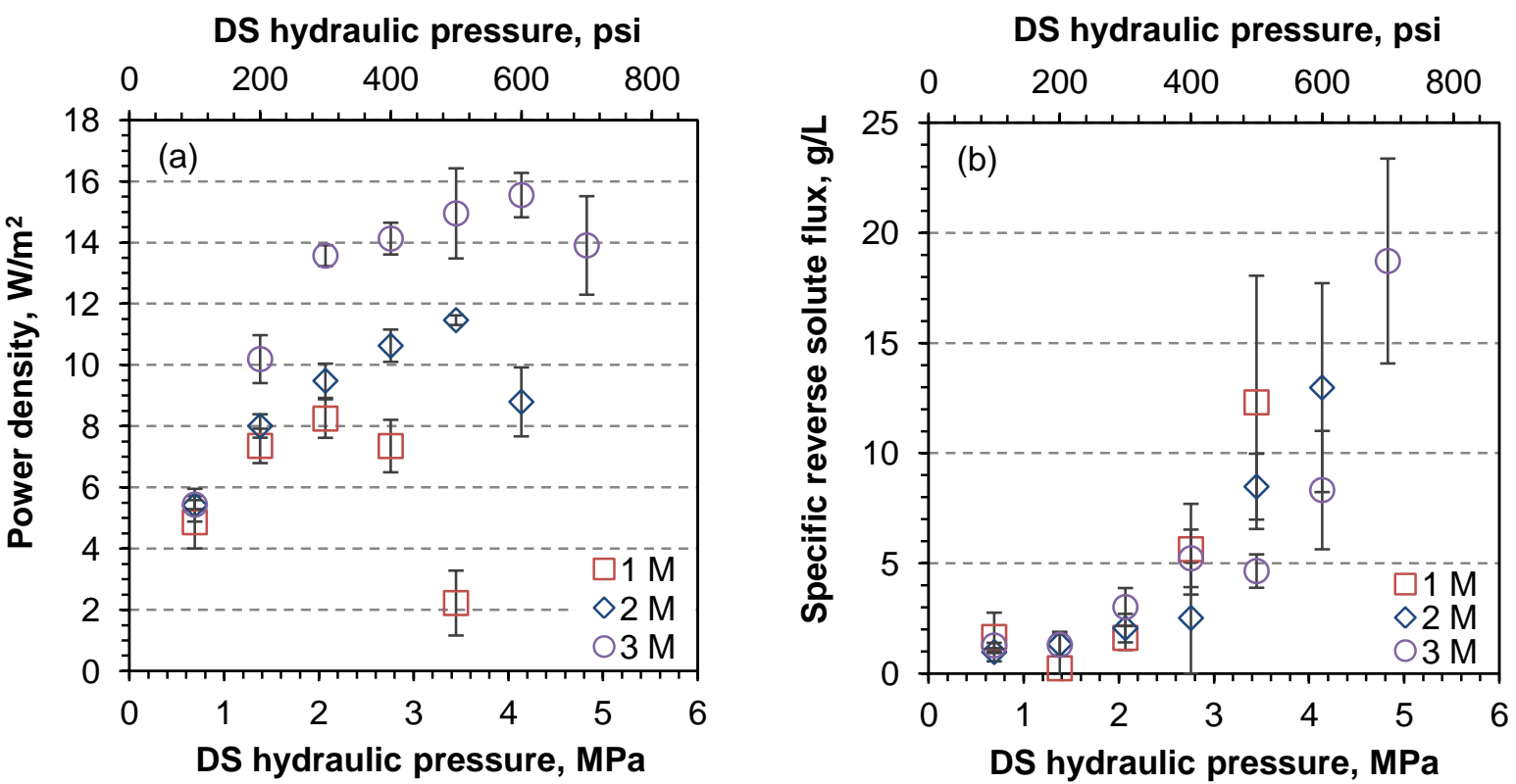

Fig. 7 (a) power density and (b) specific reverse solute flux as a function of draw solution hydraulic pressure for the HTI TFC membrane at 1, 2, and $3 \mathrm{M} \mathrm{NaCl}$ draw solution concentrations. The error bars represent the standard error amongst membrane coupons. Two parallel 20-channel spacers were used in the feed channel and one 20-channel spacer with an extruded mesh spacer was used in the draw solution channel. 
Although the HTI TFC membrane can be operated at $4.8 \mathrm{MPa}(700 \mathrm{psi})$ with a $3 \mathrm{M} \mathrm{NaCl}$ draw solution, when operated over a prolonged period of time (Fig. 8) the water flux decreased and the specific reverse solute flux increased. The decrease in permeability and selectivity indicates that the membrane was deforming and losing its integrity at high operating pressures. Membrane deformation increases ICP, which subsequently lowers power density in PRO [29, 35]. Deformation of the HTI TFC membrane at high operating pressures (>3.5 MPa) is further confirmed by evaluating membrane characteristics (Fig. 9), modeling results (Table 3), and SEM micrographs (Fig. 10).

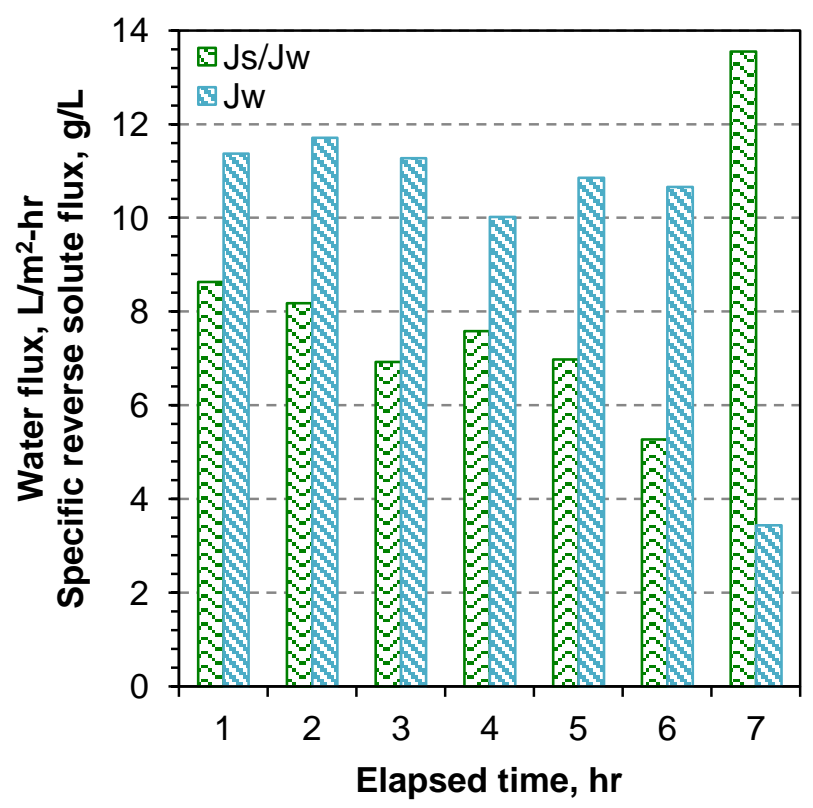

Fig. 8. Water flux and normalized reverse solute flux as a function of elapsed time for the HTI TFC membrane operated at applied hydraulic pressure of 4.8 MPa (700 psi) (TMP of 4.5 MPa) and $3 \mathrm{M} \mathrm{NaCl}$ draw solution.

Theoretical maximum power densities for 1,2 , and $3 \mathrm{M} \mathrm{NaCl}$ draw solutions were modeled and compared to maximum experimental power densities (results from Fig. 7) and are summarized in Table 3. The theoretical maximum power density was modeled using HTI TFC membrane characteristics (determined experimentally (Table 1)) and a previously established PRO model by Yip et al. [39]. For a $1 \mathrm{M} \mathrm{NaCl}$ draw solution, modeled and experimental power densities ( 9 and $8.3 \mathrm{~W} / \mathrm{m}^{2}$, respectively) were in relatively good agreement. However, there is a large deviation between modeled and experimental power densities for the 2 and $3 \mathrm{M} \mathrm{NaCl}$ draw solutions. For the experiments performed with 2 and $3 \mathrm{M} \mathrm{NaCl}$ draw solution concentrations, the 
maximum experimental power density occurs when the applied pressure is at or greater than 3.5 $\mathrm{MPa}$, which is when the HTI TFC membrane begins to lose its mechanical stability and selectivity. Once the membrane deforms, the membrane characteristics are no longer constant and the modeled values are not valid.

Table 3. Experimental and modeled power densities for the HTI TFC membrane operated with 1,2 , and $3 \mathrm{M} \mathrm{NaCl}$ draw solution concentrations and deionized water as the feed. The power density was modeled with $\mathrm{A}, \mathrm{B}$, and $\mathrm{S}$ values of $1.63 \times 10^{-2} \mathrm{~L} / \mathrm{m}^{2}-\mathrm{hr}-\mathrm{kPa}, 1.42 \mathrm{~L} / \mathrm{m}^{2}-\mathrm{hr}$, and 295 $\mu \mathrm{m}$, respectively.

\begin{tabular}{cccccc}
\hline \multirow{2}{*}{$\begin{array}{c}\text { Draw } \\
\text { solution }\end{array}$} & $\begin{array}{c}\text { Draw solution } \\
\text { osmotic } \\
\text { concentration }\end{array}$ & $\begin{array}{c}\text { Applied } \\
\text { pressure }\end{array}$ & $\begin{array}{c}\text { Power } \\
\text { density }\end{array}$ & $\begin{array}{c}\text { Applied } \\
\text { pressure }\end{array}$ & $\begin{array}{c}\text { Power } \\
\text { density }\end{array}$ \\
\cline { 3 - 6 } $\mathrm{LaCl}$ & $\mathrm{MPa}(\mathrm{psi})$ & $\mathrm{MPa}(\mathrm{psi})$ & $\mathrm{W} / \mathrm{m}^{2}$ & $\mathrm{MPa}(\mathrm{psi})$ & $\mathrm{W} / \mathrm{m}^{2}$ \\
\hline $58(1 \mathrm{M})$ & $4.8(690)$ & $2.4(350)$ & 9 & $2.1(300)$ & 8.3 \\
$117(2 \mathrm{M})$ & $10.5(1,520)$ & $5.25(760)$ & 26 & $3.5(500)$ & 11.5 \\
$175(3 \mathrm{M})$ & $17.4(2,520)$ & $8.7(1,260)$ & 44 & $4.1(600)$ & 15.5 \\
\hline
\end{tabular}

The selectivity of the membranes compacted at 3.1 and $4.1 \mathrm{MPa}$ is shown in Fig. 9. Once operated at pressures greater than $3.5 \mathrm{MPa}$, the membrane properties change and the membrane becomes less selective. Examination of the membrane surface and cross-section with SEM imaging indicates that with increasing pressure, the finger like structure of the support layer becomes more compressed and deformed (Fig. 10). Therefore, although the HTI TFC membrane can operate up to $4.8 \mathrm{MPa}$, the membrane becomes compromised above $3 \mathrm{MPa}$ applied hydraulic pressure. At increased pressures, the membrane support layer becomes thinner, which increases the apparent tortuosity and decreases the porosity. The overall increase in tortuosity and decrease in porosity results in an increased membrane structural parameter and decreased PRO power densities. 


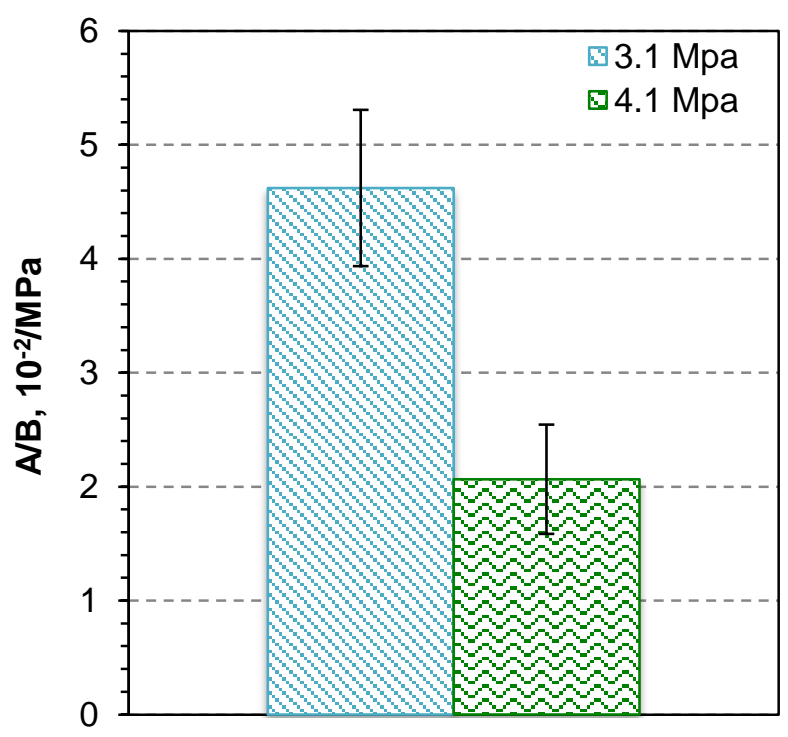

Fig. 9. Membrane water/solute selectivity (A/B) for the HTI TFC FO membrane after precompaction at $3.1 \mathrm{MPa}(\sim 450 \mathrm{psi})$ and $4.1 \mathrm{MPa}(\sim 600 \mathrm{psi})$. The error bars represent the standard error amongst membrane coupons.

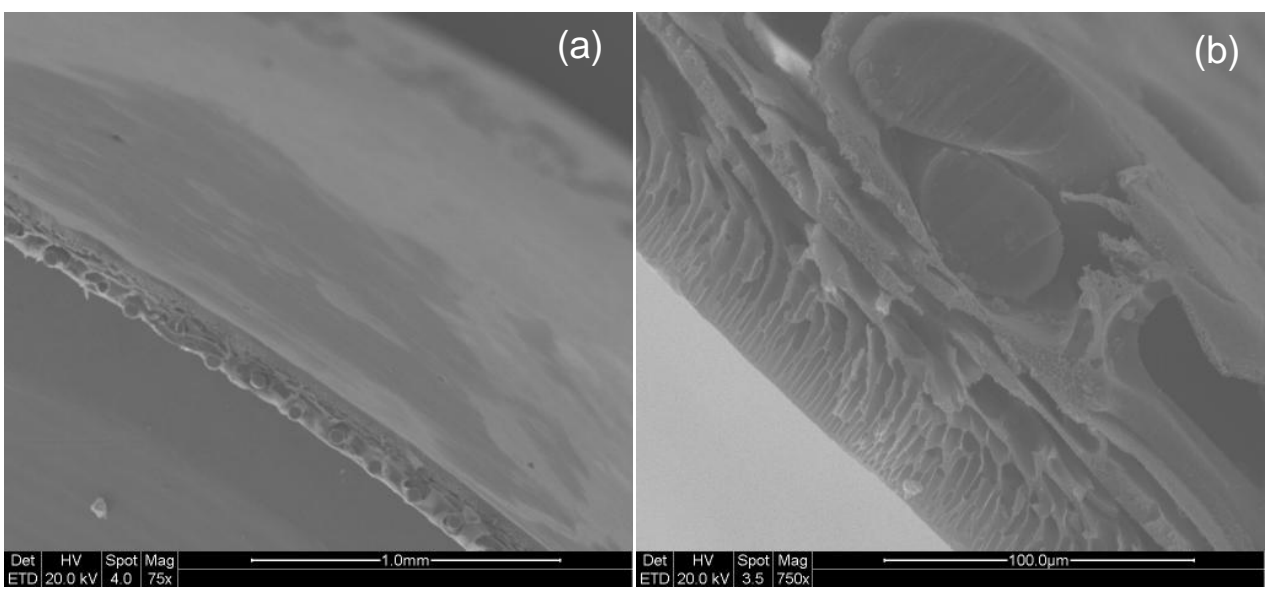

50

51

52

53

54

55

56

57

58

59

60

61

62 

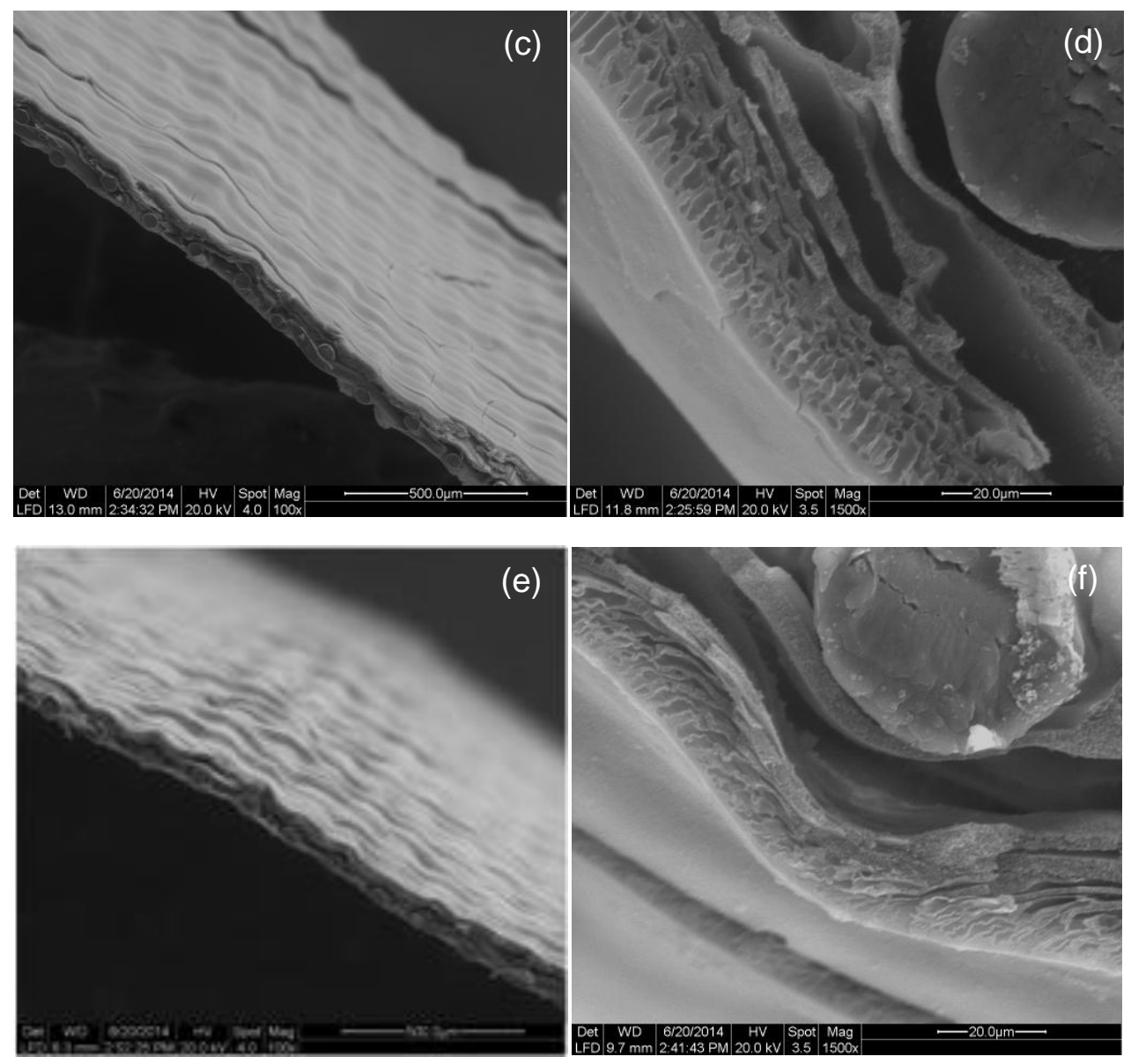

Fig. 10. SEM micrographs of the HTI TFC virgin membrane (a) surface and (b) cross section; after compaction at $3.1 \mathrm{MPa}$ (450 psi) (c) membrane surface and (d) cross section; and after compaction at 4.1 MPa (600 psi) (e) membrane surface and (f) cross section.

\subsection{Spacer selection}

Several spacer orientations were used to investigate their effect on mass transfer in PRO (Table 4). Feed channel spacer configurations and orientations include two 20-channel tricot spacers with both channels oriented parallel to the flow (configuration A), one channel parallel and one channel at $90^{\circ}$ to the flow (configuration B), both channels positioned at $45^{\circ}$ to the flow (configuration C), and four 35-channel tricot spacers with channels oriented parallel to the feed flow (configuration D). The draw solution spacer configurations include two extruded mesh spacers (configuration E) and one tricot spacer with one extruded mesh spacer (configuration $\mathrm{F}$ ). It is important to note that because of the small size of the flow cell, recoveries were low (i.e., low efficiencies and energy recovery); therefore, the PRO process efficiency, defined as the ratio 
of PRO power output to pumping power input (i.e., $\mathrm{W}_{\text {pro }} / \mathrm{W}_{\text {pump}}$ ), is simply a qualitative measurement used to compare the performance of different spacer orientations.

Table 4. Feed and draw solution spacer configurations and orientations used in the experiments.

\begin{tabular}{llll}
\hline $\begin{array}{l}\text { Spacers } \\
\text { configuration }\end{array}$ & Channel & Spacers used & Orientation \\
\hline A & Feed & Two 20-channel tricot & Parallel to feed flow \\
B & Feed & Two 20-channel tricot & $90^{\circ}$ to feed flow \\
C & Feed & Two 20-channel tricot & $45^{\circ}$ to feed flow \\
D & Feed & Four 35-channel tricot & Parallel to feed flow \\
E & Draw & Two extruded mesh spacers & $90^{\circ}$ to feed flow \\
F & Draw & One 20-channel tricot spacer and & Parallel to feed flow (tricot) \\
& & One extruded mesh spacer & $90^{\circ}$ to feed flow (mesh) \\
\hline
\end{tabular}

\subsubsection{Effect of feed spacer on power density and process efficiency}

Power density, feed channel pressure drop, and process efficiency as a function of draw solution hydraulic pressure for different feed spacer configurations (spacerless draw solution channel) are shown in Fig. 11. Feed spacer configuration $\mathrm{C}$ resulted in the highest PRO power density and process efficiency. Compared to configuration A, the feed channel pressure-drop for configuration $\mathrm{C}$ was reduced by $73 \%$, thus increasing overall process efficiency. Spacer configuration A had a high feed channel pressure drop because the spacers most likely compressed - the ridges of the spacer near the membrane collapsed into the channels of the spacer beneath it. 

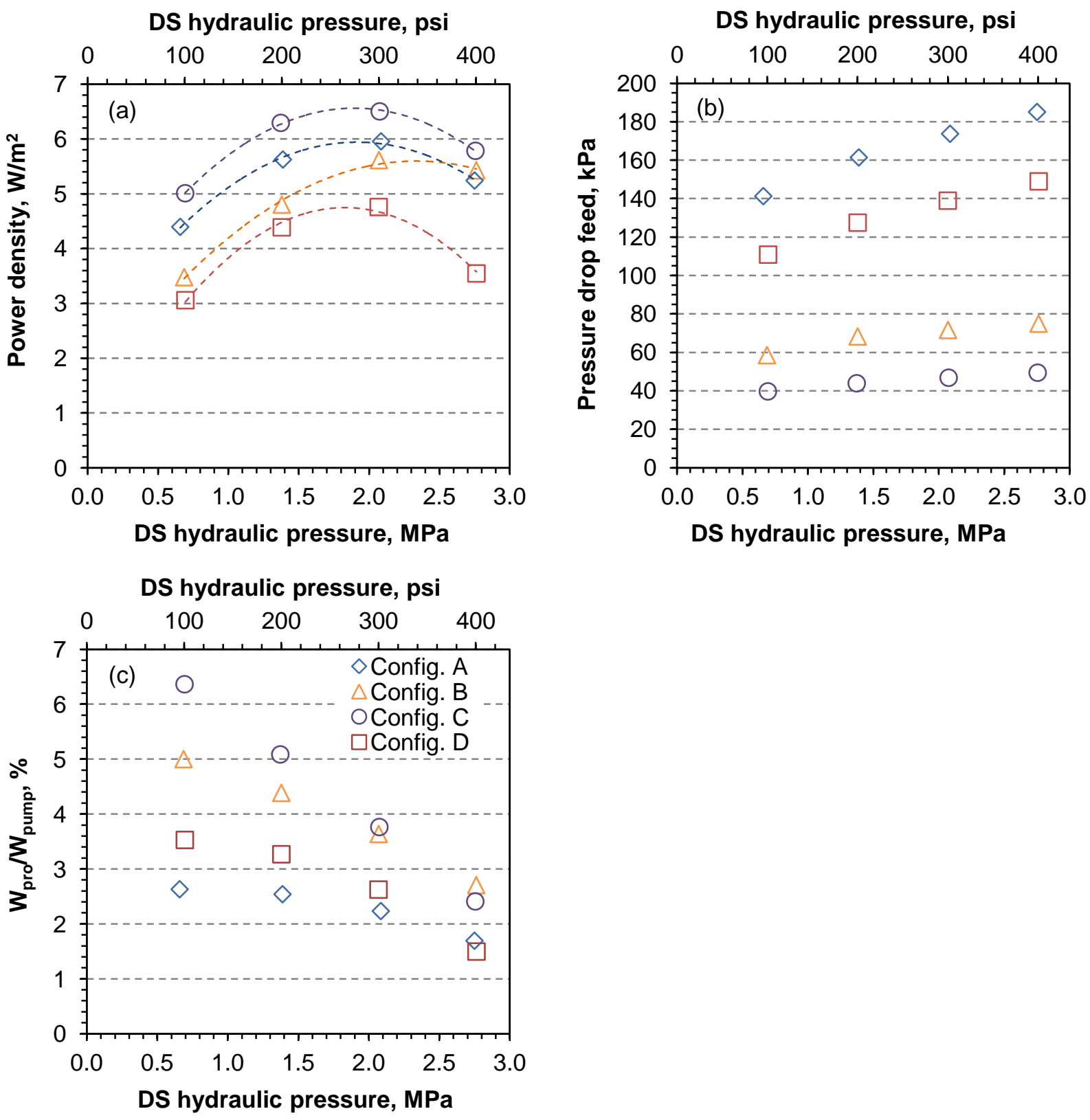

Fig 11. (a) Power density, (b) feed channel pressure drop, and (c) $\mathrm{W}_{\mathrm{pro}} / \mathrm{W}_{\text {pump }}$ as a function of draw solution pressure for the HTI TFC FO membrane with different feed spacers and spacer orientations (Table 4) and a spacerless draw solution channel. Experiments were performed with $1 \mathrm{M} \mathrm{NaCl}$ draw solution, and feed and draw solution flow rates and temperatures were kept constant at $0.5 \mathrm{~L} / \mathrm{min}$ and $20^{\circ} \mathrm{C}$, respectively.

Although power density increased with increasing applied pressure, PRO process efficiencies decreased due to increased feed channel pressure drop and increased energy demand for pumping. The flow path in spacer configuration $\mathrm{C}$ most resembles what can be described as a "corkscrew" flow pattern (Fig. 12). Changing the orientation of the feed spacers increased mass 
transfer at the feed membrane interface, thus decreasing concentration polarization at the membrane boundary layer in the draw solution channel. Da Costa et al. observed similar results for ultrafiltration; increasing the hydrodynamic angle of the spacer (i.e., direction that the fluid flows within the channel) greatly influences the hydrodynamics in spacer filled channels [40].

Although spacer configuration B has the largest hydrodynamic angle, power densities with this feed spacer configuration were not as high as the power densities for feed spacer configuration $\mathrm{C}$. In spacer configuration $\mathrm{B}$, the spacer adjacent to the membrane was oriented perpendicular to the feed flow and the spacer adjacent to the flow cell had its channels parallel to the feed flow. The feed stream most likely flowed preferentially in the path of least resistance (spacer parallel to flow), limiting mass transfer at the feed-membrane interface.

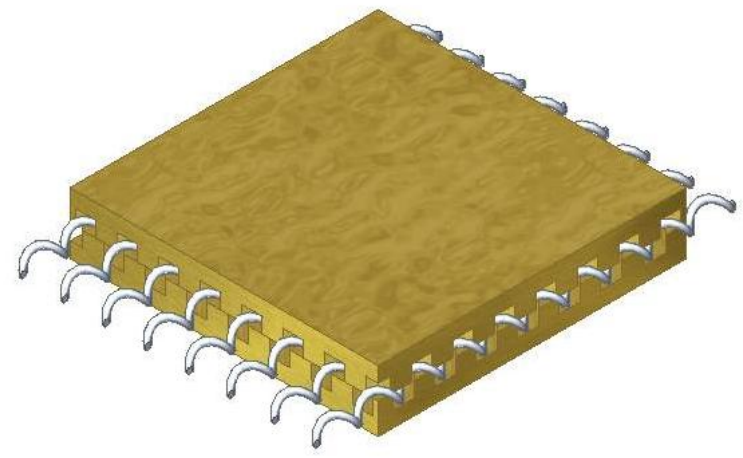

Fig. 12. Schematic of corkscrew flow for $45^{\circ}$ feed spacer orientation.

The motivation for using dense feed channel spacers (35-channel tricot) was to provide additional membrane support and reach higher membrane burst pressures. However, the dense tricot spacers did not result in higher burst pressures; it actually reduced the effective membrane area (increased shadow effect), limited mass transfer, and lowered power density. Furthermore, use of the dense spacers resulted in higher feed channel pressure drops and lower PRO process efficiencies.

\subsubsection{Effect of draw solution spacer on process performance}

Power density and process efficiency as a function of draw solution hydraulic pressure for different draw solution spacer configurations is shown in Fig. 13. The best-case feed spacer configuration (C) was used for these experiments. Compared to draw solution spacer 
configuration $\mathrm{E}$, configuration $\mathrm{F}$ resulted in increased power densities (76\% increase) and process efficiencies (2.5 times higher). Compared to the tricot spacer, the extruded mesh spacer has a higher voidage and thicker filaments, which result in increased turbulence [34]. Therefore, it is likely that the draw solution flows preferentially through the channels of the tricot spacer (path of least resistance), thus increasing mass transfer at the draw solution-membrane interface.
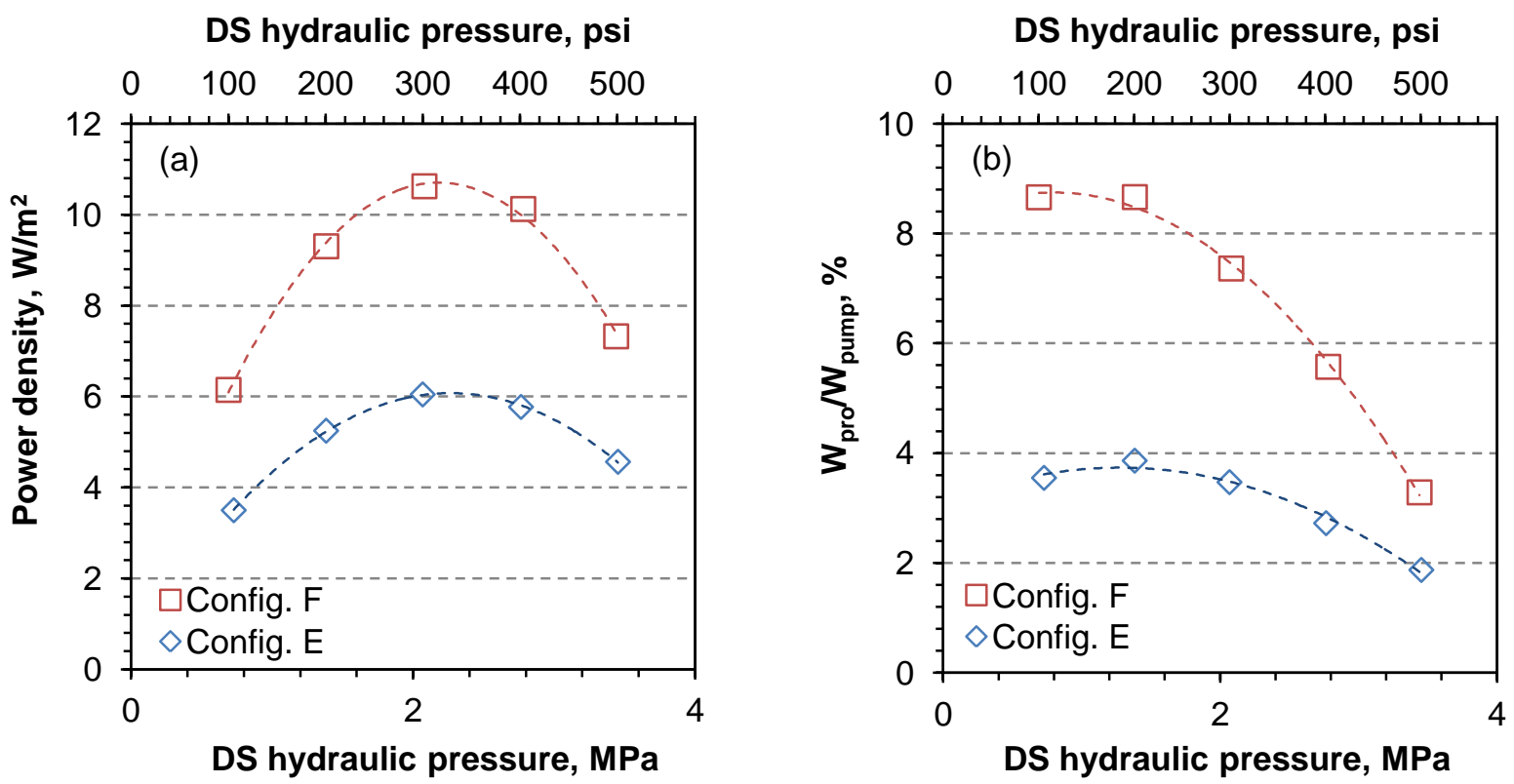

Fig. 13. (a) Power density and (b) $\mathrm{W}_{\text {pro }} / \mathrm{W}_{\text {pump }}$ as a function of applied pressure for the HTI TFC membrane with different draw solution spacer configurations ( $\mathrm{E}$ and $\mathrm{F}$ ) and configuration $\mathrm{F}$ in the feed channel. Experiments were performed with $1 \mathrm{M} \mathrm{NaCl}$ draw solution, and feed and draw solution flow rates and temperatures were kept constant at $0.5 \mathrm{~L} / \mathrm{min}$ and $20^{\circ} \mathrm{C}$, respectively.

\subsubsection{Best-case spacer configurations}

Experiments were performed with the best-case feed and draw solution spacer configurations: configuration $\mathrm{C}$ in the feed channel and configuration $\mathrm{F}$ in the draw solution channel. Water flux and specific reverse solute flux as a function of draw solution hydraulic pressure is shown in Fig. 14. The orange asterisks represent the maximum power densities from experimental results shown in Fig. 7. Implementing this unique feed spacer orientation increased power densities from previous experiments by 28,31 , and $46 \%$ for 1,2 , and $3 \mathrm{M} \mathrm{NaCl}$ draw solutions, respectively. Selection of spacers that increase process performance is impactful in future module design and system performance. 
Although this unique feed spacer orientation was impactful in increasing power densities, power densities are still not as high as other reported values for HTI TFC membranes $\left(60 \mathrm{~W} / \mathrm{m}^{2}\right.$ operated with $3 \mathrm{M} \mathrm{NaCl}$ draw solution, cross flow velocity of $21.4 \mathrm{~cm} / \mathrm{s}$, and operating temperature of $25^{\circ} \mathrm{C}$ ) [28]. In addition to increased flow velocities and elevated temperatures, the effective membrane area in the other study was six times smaller than the membrane area in this study $\left(0.002 \mathrm{~m}^{2}\right.$ vs. $\left.0.012 \mathrm{~m}^{2}\right)$ and experiments were performed over a shorter duration (35 minutes vs. two hours). Although larger membrane areas result in increased recoveries, effective membrane power densities are lowered. As water permeates from the low concentration feed stream into the higher concentration draw solution stream, the driving force and hence power densities decrease over the length of the module. Furthermore, operating membranes at high pressures over prolonged periods of time result in lower water fluxes (and hence power densities) and higher specific reverse solute fluxes, as illustrated in Fig. 8.
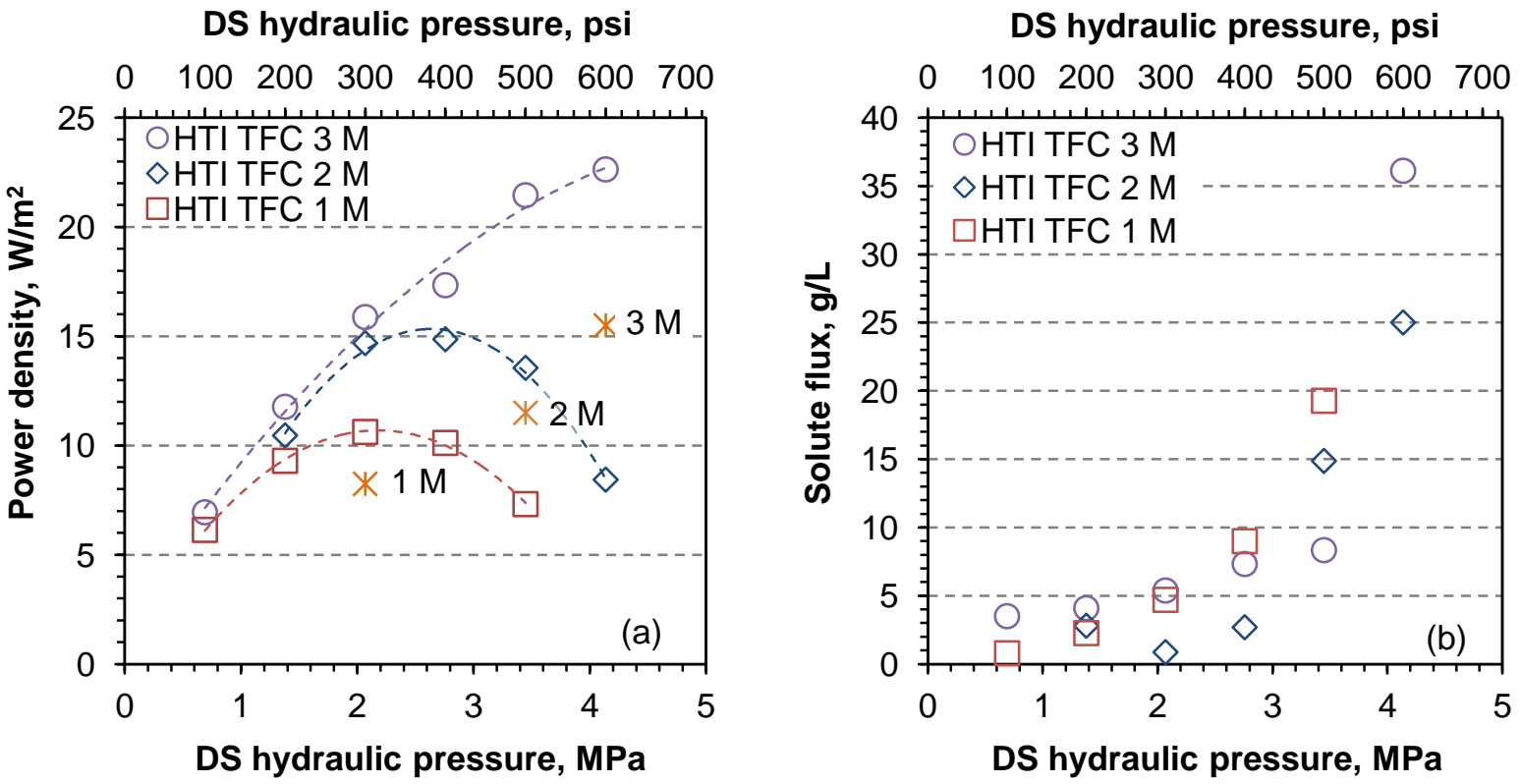

Fig. 14. (a) Power density and (b) specific reverse solute flux for the best-case spacer configuration (configuration $\mathrm{C}$ in the feed channel and configuration $\mathrm{F}$ in the draw solution channel) at 1,2 , and $3 \mathrm{M} \mathrm{NaCl}$ draw solution. The orange asterisks represent the maximum power densities from results shown in Fig. 7 (configuration $\mathrm{A}$ in the feed channel and configuration $\mathrm{F}$ in the draw solution channel). 


\subsection{Flow conditions}

Power density, feed pressure drop, and PRO process efficiency as a function of feed crossflow velocity are shown in Fig. 15, where each data series represents a different draw solution cross-flow velocity. Similar to other findings [12], power density increases with increasing feed cross-flow velocity. Compared to draw solution cross-flow velocities, increasing feed cross-flow velocity has a higher impact on membrane power densities, indicating that mass transfer in the feed stream is more critical to process performance. Increasing the feed flow velocity from 0.026 to $0.13 \mathrm{~m} / \mathrm{s}$ resulted in a $48 \%$ increase in power density; however, when the draw solution velocity was increased from 0.026 to $0.13 \mathrm{~m} / \mathrm{s}$, power density increased by only $36 \%$. Although increasing feed and draw solution cross-flow velocities result in increased power densities, PRO process efficiency is reduced due to increased energy demand for pumping.
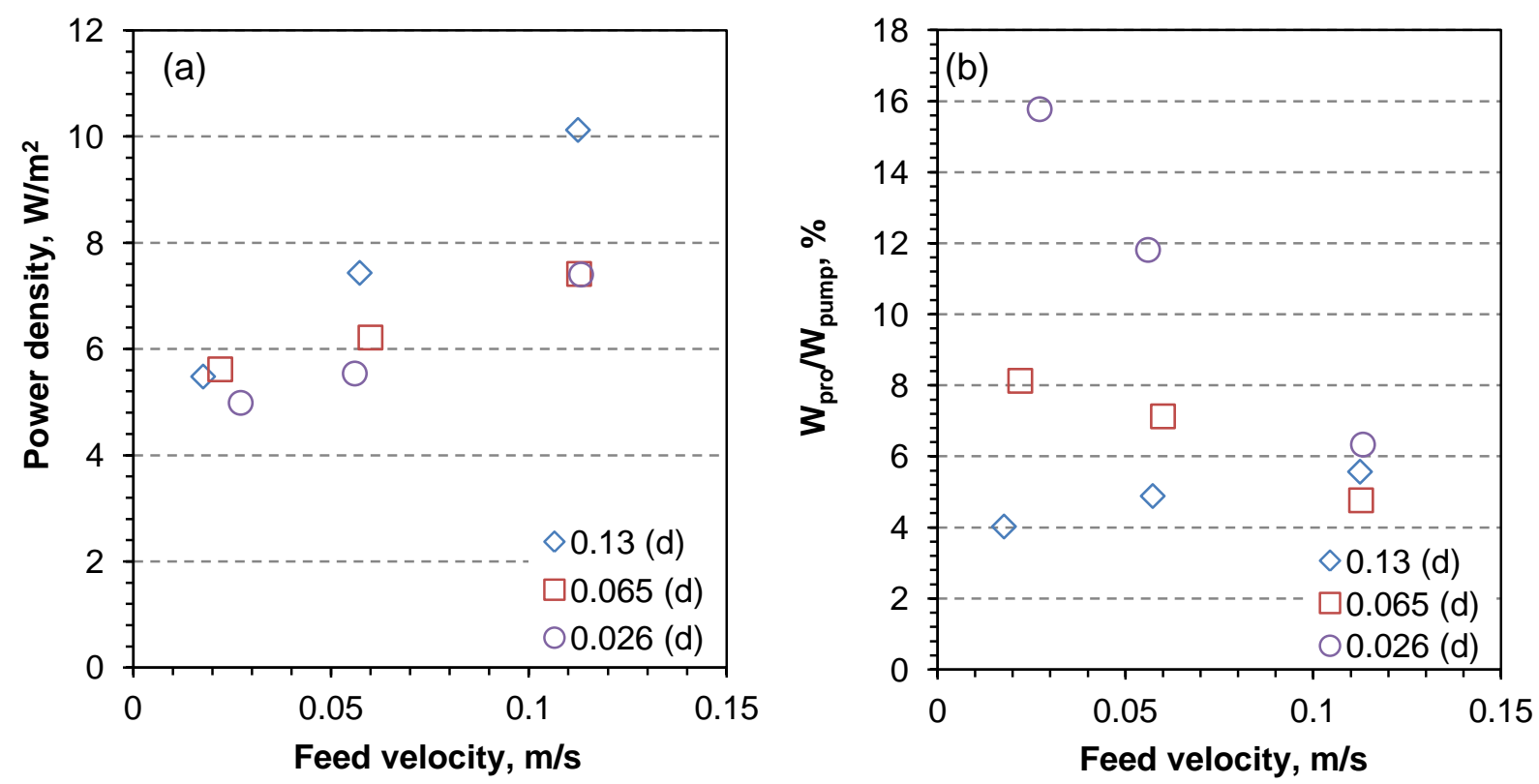

Fig. 15. (a) Power density and (b) $\mathrm{W}_{\mathrm{pro}} / \mathrm{W}_{\text {pump }}$ as a function of feed cross-flow velocity for the HTI TFC membrane operated with $1 \mathrm{M} \mathrm{NaCl}$ draw solution at $2.76 \mathrm{MPa}$ (400 psi) hydraulic pressure, spacer configuration $\mathrm{C}$ in the feed channel, and spacer configuration $\mathrm{F}$ in the draw solution channel.

\section{Conclusions}

Several commercial FO membranes were investigated for use in PRO. The HTI TFC membrane was found to be the best membrane for PRO among the four membranes investigated in this study. This membrane has the highest selectivity and mechanical stability, which result in 
high PRO power densities. This study established that the HTI TFC membrane can withstand operating pressures of up to $3.5 \mathrm{MPa}$ (500 psi) before significant membrane deformation occurs, which leads to higher ICP and decreased process performance. The specific reverse solute flux for the HTI TFC membrane was found to sharply increase at hydraulic pressures exceeding 2.0 $\mathrm{MPa}$, which has significant impact in closed-loop PRO systems. Furthermore, membrane characteristics and performance change once the membrane is deformed and modeled results are no longer valid. The use of unique feed and draw solution spacers and orientations tested in this study enhanced mass transfer through the membrane, achieving a theoretical PRO power density of more than $22 \mathrm{~W} / \mathrm{m}^{2}$, which is a $46 \%$ improvement from other spacer orientations. Reducing both feed and draw solution flow rates resulted in four fold increase in overall PRO process efficiencies (4 to 16\%). Furthermore, decreasing feed and draw solution flow rates resulted in lower parasitic pumping losses and decreased capital pumping costs. Although increased PRO power densities continue to be realized, PRO membrane development, module design, and pilot scale testing are essential for enabling PRO commercialization.

\section{Acknowledgments}

The authors would like to thank DOE/ARPA-e (Award No. DE-AR0000306) and EPA-STAR (Fellowship No. 91746401-0) for the financial support of this research. Special thanks to Mr. John Bush for his technical support with SEM imaging, to Mr. Tani Cath and Mr. Mike Veres for their technical support constructing the test system, and to HTI and Oasys Water for providing membranes and technical support.

\section{References}

[1] R.G. S. Esterly, 2013 Renewable Energy Data Book, in: K. Haas (Ed.), National Renewable Energy Laboratory, Washington, D.C., 2013.

[2] Annual Energy Outlook 2014 Early Release Overview, U.S. Energy Information Administration, (2014).

[3] J. Tollefson, Power from the oceans: Blue energy, Nature 508 (2014) 302-304.

[4] A. Achilli, A.E. Childress, Pressure retarded osmosis: From the vision of Sidney Loeb to the first prototype installation - Review, Desalination, 261 (2010) 205-211.

[5] S. Loeb, Production of energy from concentrated brines by pressure-retarded osmosis : I. Preliminary technical and economic correlations, J. Membr. Sci., 1 (1976) 49-63. 

possibilities of hydroelectric power by pressure-retarded osmosis, Desalination, 141 (2001) 8591.

[7] F. Helfer, C. Lemckert, Y.G. Anissimov, Osmotic power with pressure retarded osmosis: Theory, performance and trends - A review, J. Membr. Sci., 453 (2014) 337-358.

[8] Y.C. Kim, M. Elimelech, Potential of osmotic power generation by pressure retarded osmosis using seawater as feed solution: Analysis and experiments, J. Membr. Sci., 429 (2013) 330-337.

[9] T. Thorsen, T. Holt, The potential for power production from salinity gradients by pressure retarded osmosis, J. Membr. Sci., 335 (2009) 103-110.

[10] S.E. Skilhagen, J.E. Dugstad, R.J. Aaberg, Osmotic power - power production based on the osmotic pressure difference between waters with varying salt gradients, Desalination, 220 (2008) 476-482.

[11] K. Gerstandt, K.V. Peinemann, S.E. Skilhagen, T. Thorsen, T. Holt, Membrane processes in energy supply for an osmotic power plant, Desalination, 224 (2008) 64-70.

[12] A. Achilli, J.L. Prante, N.T. Hancock, E.B. Maxwell, A.E. Childress, Experimental results from RO-PRO: A next generation system for low-energy desalination, Environ. Sci. Technol., 48 (2014) 6437-6443.

[13] A. Altaee, G. Zaragoza, A. Sharif, Pressure retarded osmosis for power generation and seawater desalination: Performance analysis, Desalination, 344 (2014) 108-115.

[14] J.L. Prante, J.A. Ruskowitz, A.E. Childress, A. Achilli, RO-PRO desalination: An integrated low-energy approach to seawater desalination, Applied Energy, 120 (2014) 104-114.

[15] S. Lin, N.Y. Yip, T.Y. Cath, C.O. Osuji, M. Elimelech, Hybrid pressure retarded osmosismembrane distillation system for power generation from low-grade heat: Thermodynamic analysis and energy efficiency, Environ. Sci. Technol., 48 (2014) 5306-5313.

[16] R.L. McGinnis, M. Elimelech, J. McCutcheon, Osmotic heat engine, US 20100024424 A1, Feb. 4, 2010 (2010).

[17] R.L. McGinnis, J.R. McCutcheon, M. Elimelech, A novel ammonia-carbon dioxide osmotic heat engine for power generation, J. Membr. Sci., 305 (2007) 13-19.

[18] J.R. McCutcheon, R.L. McGinnis, M. Elimelech, A novel ammonia-carbon dioxide forward (direct) osmosis desalination process, Desalination, 174 (2005) 1-11.

[19] A. Achilli, T.Y. Cath, A.E. Childress, Power generation with pressure retarded osmosis: An experimental and theoretical investigation, J. Membr. Sci., 343 (2009) 42-52.

[20] C. Klaysom, T.Y. Cath, T. Depuydt, I.F.J. Vankelecom, Forward and pressure retarded osmosis: potential solutions for global challenges in energy and water supply, Chem. Soc. Rev., 42 (2013) 6959-6989.

[21] J.R. McCutcheon, M. Elimelech, Influence of concentrative and dilutive internal concentration polarization on flux behavior in forward osmosis, J. Membr. Sci., 284 (2006) 237247.

[22] W.A. Phillip, J.S. Yong, M. Elimelech, Reverse draw solute permeation in forward osmosis; modeling and experiments Environ. Sci. Technol., 44 (2010) 5170-5176. 
[23] A. Achilli, A.E. Childress, Pressure - Retarded Osmosis, in: Encyclopedia of Membrane Science and Technology, 2013.

[24] J.R. McCutcheon, R.L. McGinnis, M. Elimelech, Desalination by ammonia-carbon dioxide forward osmosis: Influence of draw and feed solution concentrations on process performance, J. Membr. Sci., 278 (2006) 114-123.

[25] N.Y. Yip, M. Elimelech, Performance limiting effects in power generation from salinity gradients by pressure retarded osmosis, Environ. Sci. Technol., 45 (2011) 10273-10282.

[26] G.T. Gray, J.R. McCutcheon, M. Elimelech, Internal concentration polarization in forward osmosis: role of membrane orientation, Desalination, 197 (2006) 1-8.

[27] S. Zhao, L. Zou, Relating solution physicochemical properties to internal concentration polarization in forward osmosis, J. Membr. Sci., 379 (2011) 459-467.

[28] A.P. Straub, N.Y. Yip, M. Elimelech, Raising the bar: Increased hydraulic pressure allows unprecedented high power densities in pressure-retarded osmosis, Environ. Sci. Technol. Lett., 1 (2013) 55-59.

[29] Q. She, D. Hou, J. Liu, K.H. Tan, C.Y. Tang, Effect of feed spacer induced membrane deformation on the performance of pressure retarded osmosis (PRO): Implications for PRO process operation, J. Membr. Sci., 445 (2013) 170-182.

[30] C.P. Koutsou, S.G. Yiantsios, A.J. Karabelas, A numerical and experimental study of mass transfer in spacer-filled channels: Effects of spacer geometrical characteristics and Schmidt number, J. Membr. Sci., 326 (2009) 234-251.

[31] J. Schwinge, D.E. Wiley, A.G. Fane, Novel spacer design improves observed flux, J. Membr. Sci., 229 (2004) 53-61.

[32] J. Schwinge, P.R. Neal, D.E. Wiley, D.F. Fletcher, A.G. Fane, Spiral wound modules and spacers: Review and analysis, J. Membr. Sci., 242 (2004) 129-153.

[33] C.C. Zimmerer, V. Kottke, Effects of spacer geometry on pressure drop, mass transfer, mixing behavior, and residence time distribution, Desalination, 104 (1996) 129-134.

[34] A.R. Da Costa, A.G. Fane, D.E. Wiley, Spacer characterization and pressure drop modelling in spacer-filled channels for ultrafiltration, J. Membr. Sci., 87 (1994) 79-98.

[35] Y.C. Kim, M. Elimelech, Adverse impact of feed channel spacers on the performance of pressure retarded osmosis, Environ. Sci. Technol., 46 (2012) 4673-4681.

[36] T.Y. Cath, M. Elimelech, J.R. McCutcheon, R.L. McGinnis, A. Achilli, D. Anastasio, A.R. Brady, A.E. Childress, I.V. Farr, N.T. Hancock, J. Lampi, L.D. Nghiem, M. Xie, N.Y. Yip, Standard methodology for evaluating membrane performance in osmotically driven membrane processes, Desalination, 312 (2013) 31-38.

[37] Oasys Water Expands to Support Commercialization and Manufacturing of IndustryPioneering Forward Osmosis Systems, in: Newsroom, Oasys Water, Boston, MA, 2014.

[38] T. Pankratz, Forward osmosis tech lab opens, Water Desalinaiton Report, 50 (2014) 3. 
[39] N.Y. Yip, A. Tiraferri, W.A. Phillip, J.D. Schiffman, L.A. Hoover, Y.C. Kim, M. Elimelech, Thin-film composite pressure retarded osmosis membranes for sustainable power generation from salinity gradients, Environ. Sci. Technol., 45 (2011) 4360-4369.

[40] A.R. Da Costa, A.G. Fane, C.J.D. Fell, A.C.M. Franken, Optimal channel spacer design for ultrafiltration, J. Membr. Sci., 62 (1991) 275-291. 
Feed spacer orientations

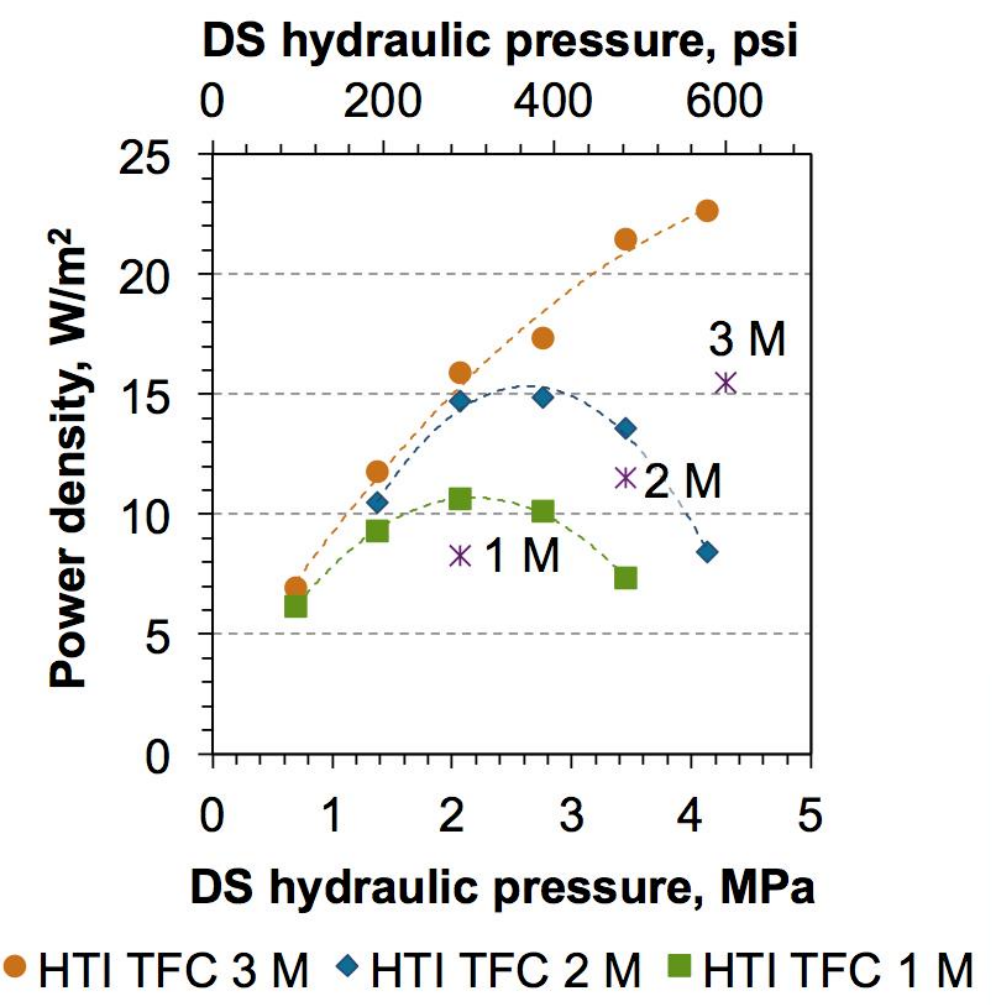

Parallel to flow $*$
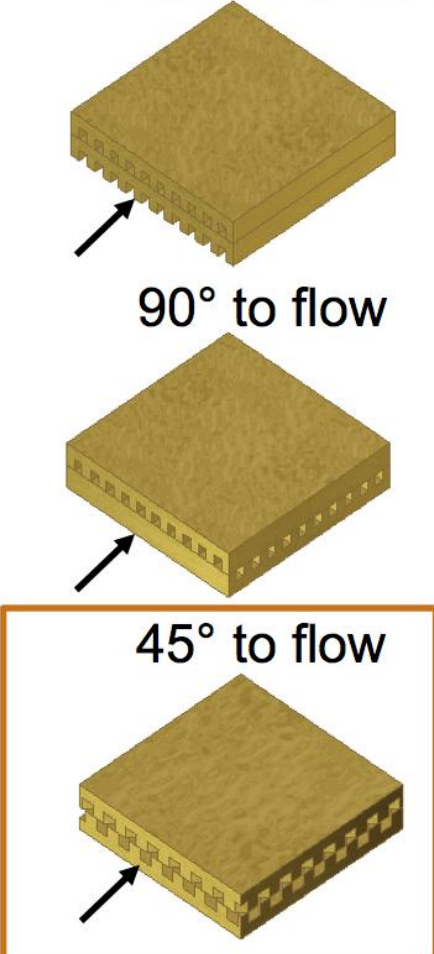